\title{
THE FIRST BULGARIAN STEPS IN THE DEVELOPMENT OF HERITAGE
}

\section{Oleksii Prysiazhniuk ${ }^{1}$}

DOI: https://doi.org/10.30525/978-9934-26-050-6-19

In the period after the Liberation from Turkish rule legislation was created in Bulgaria that clearly formulated the goals, objectives and functions of museums, and formed a comprehensive structure for the protection of cultural heritage. In the Principality of Bulgaria, with the assistance of the Russian administration, under the leadership of Prince Alexander Dondukov-Korsakov and Count Peter Alabin, in 1878 a public library with a museum was created. In the southern part of the country, which is called Eastern Rumelia and which until 1908 remains an autonomous Turkish province, the Directorate of Public Education preserves the historical heritage. The Russian Archaeological

\footnotetext{
${ }^{1}$ South Ukrainian National Pedagogical University named after K.D. Ushynsky, Ukraine
} 
Institute in Constantinople also provides active support in the research of Bulgarian antiquities [1].

The newly created Bulgarian state is taking a series of legislative measures to preserve historical and cultural monuments. On May 1, 1882, the first act related to museum business was published - it is the «Public Administrative Rules on the Organization and Management of Regional Libraries and Museums», and since 1888 the «Temporary Rules for Scientific and Literary Enterprises» have been in force [2] The first section says that all undiscovered antiquities belong to the state: «all antiquities, regardless of where they are, are state property» [2]. This document first recorded that the removal of monuments occurs only with the permission of the Ministry of Education. Then, the procedure for the purchase of finds and permits for archaeological excavations, which are issued by the Ministry of Education, is determined. The second section of the Temporary Rules is devoted to the search and description of folklore and ethnographic materials: folk songs, sayings, riddles, traditions, customs, and much more. They are collected, processed and published by the Ministry of Education [2]. For this, the first budget of 60 thousand leva was allocated in the budget of the ministry [4, p. 49]. Temporary rules for a short period served the purpose of organizing a number of archaeological and ethnographic studies in the country. These are the first legislative decrees that limited hunters of antiquities and those who tried to take Bulgarian historical and cultural monuments abroad. Temporary rules also govern Book Companies, i.e. they also laid the foundations of publishing in the country.

A fundamental change in state policy in the field of antiquities occurred with the adoption on November 27, 1889 of the «Law on the Search for Antiquities and the Support of Scientific and Literary Enterprises» [2]. Its action covers a wide range of protection of monuments - coins, historical documents and materials of verbal culture [3, p. 151]. The law consists of fifty articles, divided into three sections: Section I. On the search for antiquities and the promotion of scientific and publishing activities [2, art. 1-21]; Section II. Collection and description of verbal materials [2, art. 22-31]; Section III. Publishing activities [2, art. 32-50].

Its first section is devoted to the search for antiquities - coins, monuments, statues, tombs, weapons, guns, as well as documents - manuscripts, old printed books [2, art. 1-21].

Article 1 of the Law expressly emphasizes that all «undiscovered materials and ancient objects, wherever they are, belong to the state» [2, art. 1].

The law governs the purchase of antiques by their owners or the discovery by archaeological sites with the permission of the Ministry of Education. The assessment of monuments and documents is carried out by a commission appointed by the ministry [2, art. 4]. Those who submitted their old 
manuscripts, old books, costumes, coins, guns (not artillery implements, but tools and agricultural implements - implements) and the like [2, art. 6] also receive a reward. A curious detail in the assessment of these ancient books, monuments and materials is the democratic way of forming a committee for their assessment - one representative of the ministry and its owner [2, art. 6].

Even more interesting is the decision of the law, if the two parties do not agree on a price, «the assessment is carried out by the Cabinet of Ministers» [2, art. 6]. The fact that only the Cabinet of Ministers is engaged in the assessment of controversial monuments, only indicates that the Bulgarian state sets itself the task of searching and collecting under its protection all significant historical and cultural monuments and documents from Bulgarian lands.

Article 8 states that «discovered immovable antiquities, such as temples, fortresses and others, wherever they are, are under the control of local authorities and are the property of the government» [2, art. 8]. Thus, the state establishes control over the monuments and monitors their preservation.

The following several articles of the law detail the order of archaeological excavations, their control by the Ministry of Education and the procedure for the purchase of finds by the state [2, art. 9-16]. Newly discovered movable monuments must be described and transferred for payment through local authorities to the Ministry of Education [2, art. 17]. Thus, the state seeks to preserve and preserve movable and immovable monuments in the country for several generations.

The export of antiquities is carried out in accordance with article 8 of the Law on Customs and only according to the lists approved by the Ministry of Education. All antique items that are exported «secretly», i.e. illegally, must be confiscated by the state [2, art. 19]. At the same time, the Ministry of Education organizes scientific expeditions to various parts of the country with the aim of systematically collecting movable monuments and describing immovable monuments [2, art. 21].

The second section of the Law is devoted to the collection of verbal materials: songs, sayings, riddles, legends, stories and customs [2, art. 22-31]. The Ministry of Education is also entrusted with the full organization, evaluation and publication of field oral materials. Commissions of specialists select and submit newly submitted materials for printing.

The third section of the Law is devoted to «Book Companies». The state seeks to encourage the authors and publishers of the Bulgarian book by providing financial assistance, the procedure for conducting competitions for the publication of textbooks and scientific literature is indicated.

The last article 50 provides for the publication by the Ministry of a «special journal», which will publish «collected verbal materials, their descriptions and ratings, descriptions and images of various ancient objects, 
the most important reviews, as well as everything valuable that has been delivered to the Ministry in the field of antiquities and literature» [2, art. 50].

The entry into force of the first «Law on the Search for Antiquities and the Support of Scientific and Literary Enterprises» in Bulgaria was a crucial step for further work in this direction. In 1890, museums in the country have not yet been built. Archaeological excavations were carried out by enthusiasts, mainly teachers. Treasure hunters uncontrollably destroyed burial grounds and other archaeological sites. Folklore material was collected, as during the Renaissance, by school and community centers. There were no scientific institutions involved in the study of Bulgarian spiritual and material culture.

Over the 20 years of the operation of this Law, the first institutions were created to preserve the cultural heritage and protect the monuments of the richest Bulgarian cultural and historical history. The young Bulgarian state, despite the economic difficulties after the Unification, allocates more and more funds for culture and, therefore, for the purchase of antiquities. At the end of the 19th century, such appropriations were allocated: in 1889 70 thousand leva, 1890 - 90 thousand leva, 1891 - 90 thousand leva, 1892 120 thousand leva, 1893 - 143 thousand leva, 1894 - 140 thousand leva [4, p. 51]. In particular, in 1894 the budget of the National Library was 20,460 leva, and the National Museum - 9120 leva [4, p. 54].

A powerful incentive for the search, collection, scientific processing and publication of folklore and ethnographic material was the «Collection of Folk Songs, Science and Literature» in 1889. The last article of the Law on the Search for Antiquities and the Support of Scientific and Literary Enterprises provided for the creation of such a periodic body in the future to publish materials collected by the ministry. Nine years were necessary to complete the preparatory process, and finally, an extremely important scientific platform arises in the Bulgarian cultural space.

\section{References:}

1. Basargina E. Yu. (1999). Russkij arkheologicheskij institut $v$ Konstantinopole. Ocherki istorii [Russian Archaeological Institute in Constantinople. History essays]. Sankt-Peterburg: Dmitry Bulanin. (in Russian)

2. Zakon za izdirvane na starini i za spomagane nauchni i knizhovni predpriyatiya (1890) [Antiquities Search and Assistance Act for Scientific and Literary Enterprises]. State Gazette, y. XI, vol. 13, 17 yanuari.

3. Ivanova B. (2012). Bolgarskie muzei i muzejnoe zakonodatelstvo: istoriya i sovremennost [Bulgarian Museums and Museum Legislation: Past and Present]. Museological issues, no. 1(5), pp. 148-160.

4. Radeva M. (2002). Kulturnata politika na blgarskata drzhava (1885-1908) [The cultural policy of the Bulgarian state (1885-1908)]. Sofiya: Universitetsko izd-vo «Sv. Kliment Okhridski». 